\title{
Iwona Mokwa-Tarnowska
}

Gdańsk University of Technology

https://orcid.org/0000-0001-5776-0404

\section{Online Collaborative Learning to Enhance Educational Outcomes of English Language Courses}

\begin{abstract}
With various aims and objectives, syllabi of e-learning, blended learning and webenhanced courses meant for a particular group of undergraduates or postgraduates, may vary substantially. However different they are, they are likely to show behaviourist ideas embodied in instructional design. A plethora of online tools (text based, image based, multimodal production and collaborative ones) can increase students' learning experiences, as they offer opportunities for interactions that are not available in a traditional, instructivist classroom setting. Thus, a university language course with web-enhanced components offers more versatile learning options than face-to-face classes, which may result in students becoming more competent and competitive workers in the years to come. By using online tools such as ThingLink, mural, quip, easel.ly, infogram and venngage to collect and critically analyse data, they learn in a new active way, in a more genuine environment. This way of engaging students helps them to achieve learning outcomes structured around communication, teamwork, media literacy and language skills. These ideas are supported by students' opinions and attitudes expressed in the surveys conducted at Gdańsk University of Technology in the years 2017-2019.

K e y w o r d s: web-enhanced language learning, online tools, hard and soft skills, e-learning, university education, collaborative project
\end{abstract}


Engaging students in various interactions, of which resulted from student exposure to a range of multi-purpose tasks, both online and blended, can help educators achieve the desired educational outcomes. Developing both hard and soft skills in an e-leaning environment enriches students' learning experience, because they have an increasingly greater number of opportunities to engage in educational activities. University courses are more likely to arouse interest, stimulate involvement and lead to satisfactory outcomes when they are developed in environments structured around pedagogical methodologies based on active learning and collaborative achievements (Kołodziejczak et al., 2015).

Problem-based learning results in an increase in complex skills, especially when it is supported by web tools (Issa et al., 2016). Having the capacity for versatile interactions, online programmes that target collaborative achievements allow their users, both teachers and students, to develop more competencies than traditional ones based on the same subject matter. They can better satisfy the needs, expectations and learning styles of Generation Z (Beall, 2016). Moreover, they can enable educators of previous generations to improve their skills to emulate the majority of their students who have been raised in a technology-rich environment. Not only do Internet-based tasks provide access to a vast number of up-to-date resources, but they also make use of different tools and their functionalities, thus giving plenty of opportunities to increase learning and teaching experiences. Academics can engage their students in more genuine interactions than those available in a traditional, face-to-face setting, and they can increase their scope of educational methods and techniques (Kołodziejczak et. al, 2017; Kemp \& Grieve, 2014).

The paper aims to show how to achieve course outcomes, which are a required element of a syllabus, through creating a project-based environment that can raise students' interest and increase their satisfaction, and how to engage both teachers and students in an active and collaborative development of various competencies. Furthermore, it attempts to investigate how effectively undergraduates involved in e-learning tasks can focus on developing hard and soft skills. The presented hypotheses are supported by survey results, analyses of students' behaviour during online activities, follow-up tests and tasks, as well as educators' opinions presented in the literature. 
Online Collaborative Learning to Enhance Educational Outcomes...

\section{Behaviourism and its Impact on the Wording of Aims, Objectives and Outcomes}

Behaviourism, being one of the most influential learning theories, started in the first half of the 20th century with research carried out by Edward Thorndike, John Watson and Ivan Pavlov into changes in animals' and people's behaviour which resulted from them having been subjected to a series of stimuli. Behaviourist scientists discovered that an animal or a child presented for some time with conditional stimuli associated with unconditional ones responded in the same way to the conditional stimuli even when they were not accompanied by the unconditional ones. This lasted for a certain period of time and eventually resulted in the "extinction" of the behaviour. They also noticed a positive role of awards (Thorndike, 1911) and reinforcers (Skinner, 1938), which strengthened a stimulus-response bond. According to neo-behaviourists, observable changes in behaviour are not only caused by conditioning, classical or operant, but also by some elements of cognition. They perceive personality, motivation and habit to be important reinforcers (Bishop et al., 2016).

The influence of behaviourism can be seen in how educators understand learner behaviour inside and outside the classroom (Jordan et al., 2008, pp. 27-31). Bloom's taxonomy of learning with its later modifications (Bloom, 1956; Bloom \& Krathwohl, 1956) classifies three domains which show hierarchical sets of behaviours. The cognitive domain, which is the most important from the educational point of view, identifies six levels related to intellectual abilities, showing the progress from Knowledge - the lowest level - to Evaluation - the highest level, through Comprehension, Application, Analysis and Synthesis. All these stages do not have to occur in the educational process, however, in order to enter any of the higher ones, one has to pass through the previous ones. Self-directed learners must reach the last one if they want to effectively use their acquired knowledge.

The hierarchy was slightly modified by Anderson and Krathwohl (2001), and supplemented with a new top level, that is, the level of Creating, which shows that people are able to create new knowledge after evaluating what they have learnt so far. The affective domain is used to categorise attitudes. From the lowest level labelled Receiving, which indicates that first people are aware of a situation, then through responding, valuing, organising and conceptualising they eventually reach the highest stage, that of Characterising by Value or Value Concept (Krathwohl et al., 1964). After passing the last stage, students have the system of values internalised. It enables them to work independently and in teams, and apply the attitudes and values they hold to problem-solving (Clark, 2004). The third domain, which

IJREL.2020.6.2.05 p. 3/21 
is called the psychomotor, concerns skills. Research into it was started by Bloom, and later completed by Dave (1975), who suggested the following hierarchical levels: Imitation, being the lowest one, Manipulation, Precision, Articulation and Naturalisation, being the highest one. All the stages show how finally, entering one after another, learners achieve the mastery of skills, and the highest level of expertise required to construct, design or create new things.

The behaviourist understanding of learner actions expressed in Bloom's Taxonomy is visible in the way course developers prepare tasks. The wording of instructions shows that they are based on behaviours described in the cognitive domain. When passing through the first level, i.e. Knowledge, learners preparing, e.g., infographics, reports, specifications, are asked to define the scope, to outline the problems found in the literature, to identify the aim and objectives, and to quote external sources by making references in an appropriate way. In the next parts, they have to describe the relevant theories, materials, equipment or machinery used, as well as to show the methods employed. When comparing, contrasting and interpreting data and facts in the Results and Findings part, they reach Bloom's levels of Comprehension and Application. They need to use the acquired knowledge to solve problems, examine and measure outcomes, calculate results, classify findings in tables, and finally illustrate them with graphs. The behaviours found in the last three stages of the original cognitive domain, i.e., Analysis, Synthesis, Evaluation, are also visible in the teacher's recommendations on how to prepare assignments.

The wording of course objectives used by developers of different e-learning programmes (Heriot-Watt University, 1999) exhibits associations with behaviourist principles (Mokwa-Tarnowska, 2017a). Objectives are often written in a learnercentred format which indicates what behaviours students will display after finishing the course, e.g. "You will be able to use formal English in writing," "You will be able to apply coherence and cohesion devices when writing a technical text," "You will be able to make a presentation," "You will be able to work in an international team." Syllabi of e-learning, blended learning and web-enhanced courses may vary substantially and may depend on various aims and objectives. They may also be meant for a particular group of undergraduates or postgraduates. However different they are, they are likely to show behaviourist ideas embodied in instructional design.

In order to measure learning outcomes, specified by means of course aims and objectives phrased in a behaviourist way, one can apply formative assessment (Cowie \& Bell, 1999, pp. 101-116; Crooks, 2001), whose purpose is to provide students with continuous feedback, which helps them increase knowledge and benefit the most from the course. This form of assessment better encourages and motivates learners during an online course or module than summative assessment (Scott, 2003; Atkin et.al, 2005) - it can be treated as positive reinforcement. 
Online Collaborative Learning to Enhance Educational Outcomes...

From the behaviourist perspective, feedback referring to underperformance has to be constructive, it must not be phrased by means of negative words. If a task is delivered online and supervised by a tutor, formative assessment plays a crucial role in developing self-directed learning, and in building learners' self-confidence. Students can learn how to assess their skills and knowledge, and what to do to improve their learning experience, which is very important if they are to become lifelong learners. Positive evaluation of progress and achievements can function as a highly motivating factor, which contributes to students feeling autonomous in self-education.

\section{Web 2.0 Tools to Support Language Learning and Attainment of Learning Outcomes}

There is a variety of Web 2.0 tools to enhance language classes for university students attending traditional courses (Mokwa-Tarnowska, 2017b). Text based tools, image based tools, multimodal production tools and collaborative tools can increase learning experiences. With their various functionalities, they offer different opportunities for teachers who can engage their students and themselves in interactions that are not available in a traditional, instructivist classroom setting (Kołodziejczak et al., 2017; Mokwa-Tarnowska et al., 2018). They can stimulate collaborative learning by doing and help students improve both hard and soft skills. This, in turn, can result in meeting university course aims and objectives, most of which in the case of learning languages focus on developing competencies that enable teamwork in the work context. Presented in a behaviourist format, learning outcomes that university education is supposed to lead to, refer to knowledge, skills, and social competence, and are divided into cognitive and behavioural ones (Austin 2012, pp. 46-47). The former identify what students will know after completing a course, and the latter what students will be able to do. In the Polish education system, learning outcomes are expressed in terms of aims and/or objectives, with the choice depending on the course. The intended results, when expressed in Polish, are thus mistakenly understood to be the achieved ones, which is seen in the choice of words. However, they are only likely to be attained, and the prediction of what will have been reached is stated in the curriculum preparation phase, and then visible in the course syllabus.

Course aims and objectives that target soft skills are difficult to fulfil, and employers across the world constantly complain that university graduates are not

IJREL.2020.6.2.05 p. 5/21 
equipped well enough with the competencies that they are looking for (NACE, 2019). Poor soft skills have been reported to be the reason why young workers have difficulty adapting to a new work environment. Thus, to prepare students for future challenges in the labour market, universities should change their course curricula to increasingly focus on the development of various competencies, not only the hard ones that are obviously of the utmost importance in university education (Mathur, 2017; Rima et al., 2017). By expanding the scope of language classes to include soft skill-based experiences, educators can create an environment that will allow them to meet goals far beyond the four fundamental language skills that contribute to one-to-one and one-to-many communication (Widła, 2019). The verification criteria chosen to check if students' achievements fulfil the requirements can refer both to traditional and online activities, combined to achieve a synergistic effect. With its tools and their functionalities, synchronous and asynchronous modes and other affordances, an e-learning environment can help educators ensure that learning outcomes meet the aims, their own needs and those of their students.

\section{Traditional Language Courses at GUT Enhanced with Online Tools}

The author of this paper uses online components to enhance her students' learning opportunities. They supplement traditional classes and focus on English for Specific Purposes (ESP) and academic English. Their goal is to introduce novelty into teaching and learning, prepare students for blended programmes and self-directed learning. They aim to create an environment suitable for the development of different hard and soft skills. Their objectives differ and depend on the subject matter and skills they target. They range from hard skills such as the writing skill and the reading skill to soft competencies, e.g. collaborative skills, time management skills, managerial skills, analytical skills and critical-thinking skills.

The last few years have seen the emergence of different Web 2.0 tools, which has resulted in a growing interest to use them in university education (Noskova et al., 2017). Due to their functionalities, they can support the development of different hard and soft competencies. So far the following tools have been tested during language courses offered by Gdańsk University of Technology (GUT) to understand how well they can support students of science and engineering: website creation and data publishing technologies such as the Moodle wiki tool, ThingLink, mural, quip, easel.ly, infogram and venngage. They have been selected to support short and long collaborative, project-based tasks.

IJREL.2020.6.2.05 p. 6/21 
Online Collaborative Learning to Enhance Educational Outcomes...

\section{Research Design and Implementation}

Since October 2016 slightly over 300 students of different GUT's faculties have developed online materials using the Web 2.0 tools mentioned above -260 have completed questionnaires on their attitudes towards the web-enhanced classes they have participated in. As many as 180 students participated in longer, i.e., threeweek, online collaborative projects, most of whom, i.e., 161, completed surveys. An analysis of the answers to selected questions is presented in this paper. It is supported by findings collected during qualitative research based on observation and answers to open-ended questions.

In the first semester of the academic year 2016/2017, two groups of students attended collaborative, web-enhanced classes, first using ThingLink and then Moodle wiki (Mokwa-Tarnowska, 2017c). The students produced a multimedia poster in the first project, later presented in class as a springboard for discussion. The second project involved compiling specifications of an apparatus or equipment invented by the students themselves to be advertised in class. Both one-week tasks entailed shifting control over the learning process to the participants. Their experience showed that one-week projects cannot effectively target the development of collaborative skills through online activities because students meet at an English class in a traditional classroom setting once a week and attend faculty lectures and seminars every day. Thus, they can discuss their duties during face-to-face meetings. Moreover, one-week projects resemble typical homework that can be done by a group of people on one computer.

Since the second semester of the academic year 2017/2018 longer, usually three-week projects have been carried out to enhance English classes. They require a substantial amount of involvement and effort - they are more intensive than the previously assigned online and traditional ones. With more duties, students are likely to work online on their own at intervals, and not together doing everything in one sitting in front of one computer. In the first phase of the research, the collaborative tools the students were asked to choose were mural, quip, and easel.ly, to be followed in the second phase by infogram and venngage, which target the collaborative creation of infographics in particular - all of which were easy to use for technically-mined undergraduates.

\section{Research Questions and Methods}

The qualitative and quantitative research into the nature of web-enhanced language classes at GUT and their impact on an increase in student competencies, both hard and soft ones, was initiated four years ago. Students' opinions and motivations shown in comments presented in class as well as answers to open-ended questions have helped to uncover some trends to be further tested in the next research phases. Two basic tools have been used so far to produce a qualitative

IJREL.2020.6.2.05 p. 7/21 
analysis: direct observation and group discussions. The quantitative research in each phase involved a paper survey. The research questions targeted in the second phase were as follows:

- What are the students' attitudes to online collaborative work during longer projects?

- How effective can online collaborative work which enhances traditional classes be in terms of learning outcomes?

- How can an online environment created to enhance traditional classes help develop hard and soft skills?

- How does an online environment affect learning outcomes?

It can be assumed that the composition of each study group was homogeneous with respect to many factors: age, intellectual capacity, interest in science and engineering, undergraduate course participation and B2-C1 level of English according to the Common European Framework of Reference for Languages. The only major difference was that both first-year and second-year students participated in the survey, which could have had an impact on their perception of collaborative work. It might be easier for second years as they are better acquainted with university requirements, have more experience related to working in teams, which is required in many subjects usually taught at a later stage, and they better know each other. Moreover, students of the third and fourth semesters of an English course usually have more experience in doing ESP tasks, including online ones. Thus, they are likely to find them easier. The data collected during the research are presented as medians, mean values or percentage, as appropriate. The comparison of groups (categorical data) was analysed with the $\chi 2$ test. All the results were considered significant at $p<0.05$. The statistical analyses were performed with STATISTICA 12.0 (StatSoft Inc.)

\section{Quantitative research - Results and Discussion}

The survey targeted the students who had participated in longer online projects, usually of 3-week duration. The respondents who participated in the projects in the second semester of the academic year 2017/2018 used mural, quip and easel.ly, their number amounted to 72, out of whom 61 completed questionnaires (17 students of Mechanical Engineering, 18 students of Telecommunication and Electronics, both groups in the first year of their English course, and 26 students of Automation and Robotics, and Medical Engineering in the second year of their English programme). Data from answers to two questions are presented in figures 5 and 6.

The cohort doing infographics in the second semester 2018/2019, using infogram and venngage, consisted of 125 students, of whom 100 completed questionnaires (14 Physics and Maths students, 16 Mechanical Engineering students, 13 
Online Collaborative Learning to Enhance Educational Outcomes...

Civil Engineering students and 23 Architecture students in the first year of their English course, as well as 17 Civil Engineering students and 17 Architecture students in the second year of their English course).

Most of the students who participated in the latest phase of the research, in the academic year 2018/2019, stated that the task allowed them to improve their data analysis skills (Figure 1). More than half of the students attending the first year of a two years' course of English were satisfied with their progress and rated it as good or acceptable (students of Physics and Mathematics: 92.85\%, students of Mechanics: 75\%, students of Civil Engineering 1: 61.54\%, students of Architecture 1: $86.96 \%$ ). The students in year two of their English course assessed their data analysis skills in a similar way (students of Civil Engineering 2: $64.7 \%$, students of Architecture 2: 94.12\%). The Architecture students' positive opinions may have resulted from being accustomed to analysing visual data, and from having had to develop a spatial imagination over the years, instrumental in architectural design. The most dissatisfied students were those of year one from Mechanical and Civil Engineering faculties, $18.75 \%$ and $15.38 \%$ respectively, for whom this was a new experience.

The students were asked to assess their contribution to the teamwork (Figure 2). A majority contributed substantially but there were a number of students who had not put enough effort into the task. Over half of the first year students in Civil Engineering considered their contribution to be substantial. All the other students who chose the same answer ranged between $30.43 \%$ and $47.07 \%$. In three groups, there were students who made no contribution $(12.5 \%$ of the students of Mechanics, $7.69 \%$ of the students of Civil engineering 1 and $11.76 \%$ of Civil Engineering 2) - they did not provide any explanation why they were inactive. When asked in class about the work all the team members had done, no student complained about their classmates being unwilling to participate in the project or not providing any support.

The students' perception of an increase in their language skills was also addressed in the survey (Figure 3). A substantial number of the respondents regarded their hard competencies as better after the task completion. They learnt new vocabulary and practiced writing IELTS style descriptions they had not attempted before. Thus, it is not surprising that a large proportion of the students noticed an improvement in their language skills. The participants who had not contributed to the projects stated that the task had not added to their competence - there is a consistency in understanding a correlation between work effort and involvement and skill improvement. However, the number of negative answers was significantly higher, which means that also some of the students who stated that they had contributed to the overall result were dissatisfied with their language skills (6.25\% of the students of Mechanical Engineering, 15.38\% of Civil Engineering

IJREL.2020.6.2.05 p. 9/21 
Iwona Mokwa-Tarnowska

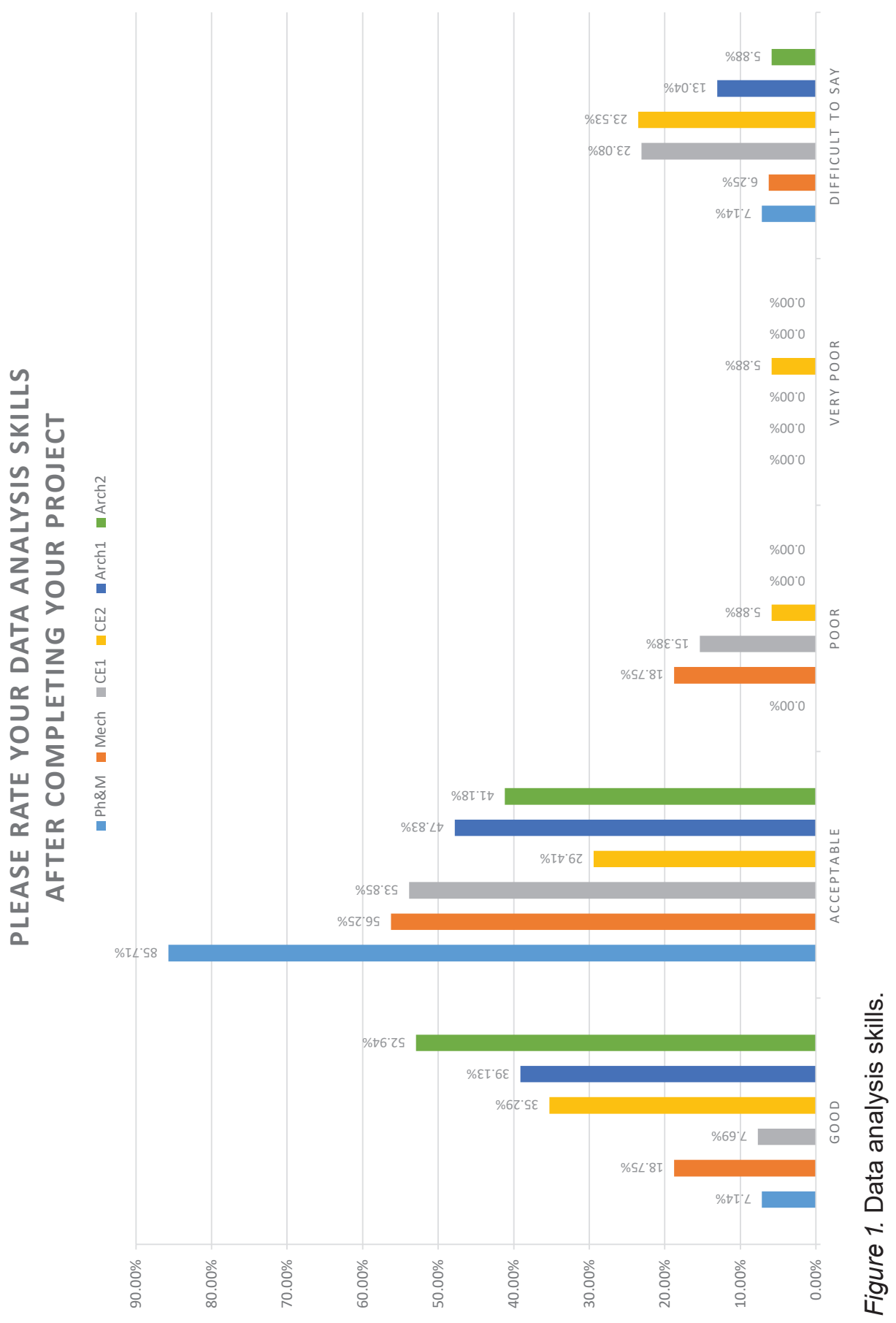

IJREL.2020.6.2.05 p. 10/21 
Online Collaborative Learning to Enhance Educational Outcomes...

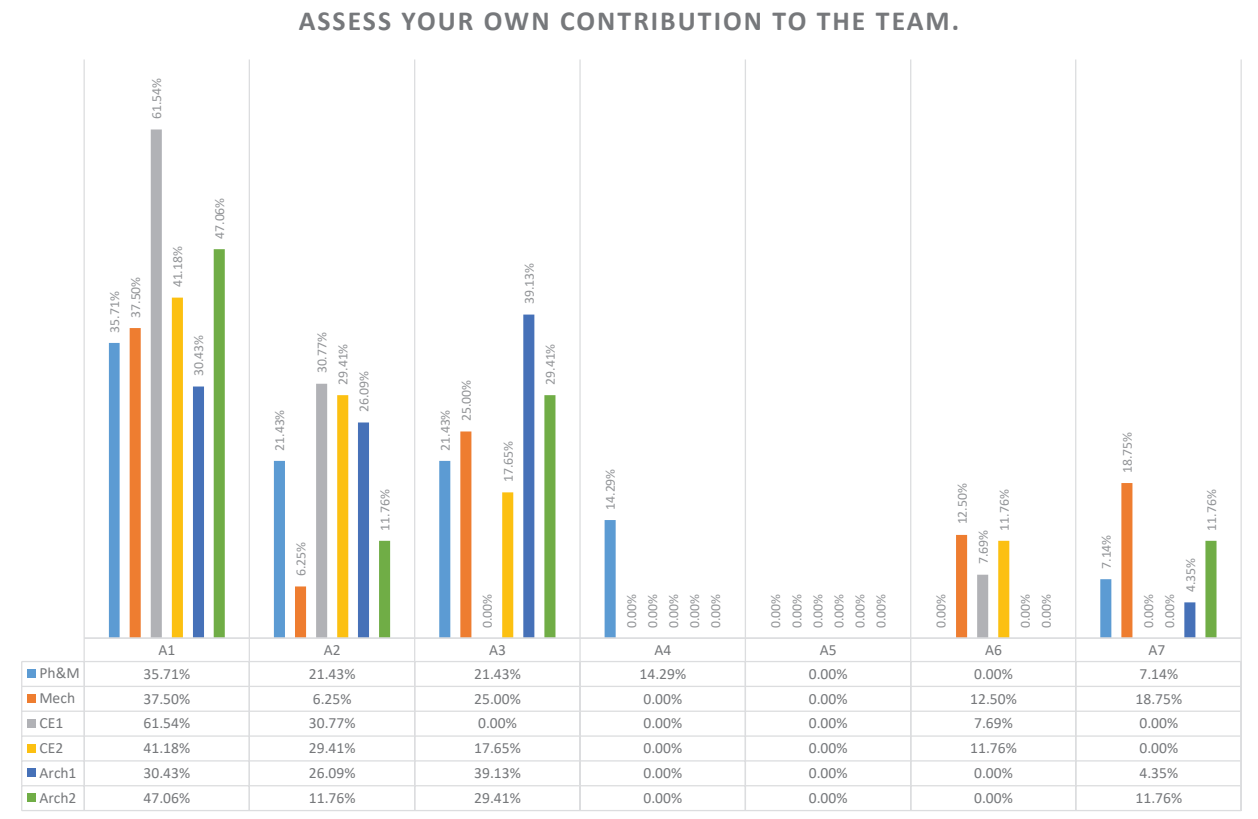

Figure 2. Contribution to team work.

N o t e: A1. My contribution was substantial. A2. I worked a lot but I should have done more. A3. My contribution was average but other team members made no complaints about it. A4. I did what I was assigned to do but other team members were not satisfied with my contribution. A5. I did too little and other team members were dissatisfied with my contribution. A6. I did nothing. A7. I have no opinion.

1, $11.77 \%$ of Civil Engineering 2, 8.7\% of Architecture 1 (plus $21.74 \%$ of those undecided)).

Figure 4 shows the respondents' opinions regarding online collaborative tasks being a part of university curriculum. Over half of the students in every group stated that traditional language classes should be supplemented with teamwork carried out in an e-learning environment (64.28\% of Physics and Mathematics students, $56.25 \%$ of Mechanics students, $76.92 \%$ of Civil Engineering 1 students, $52.94 \%$ of Civil Engineering 2 students, $86.96 \%$ of Architecture 1 students, $94.12 \%$ of Architecture 2 students). It seems that if students are accustomed to working in teams in a classroom setting, like students of Architecture, they are more inclined towards online efforts as well. It must be emphasised that one third of the students of Physics and Mathematics, the students of Mechanical Engineering and the students of Civil Engineering in year 2 would not like to learn in an active collaborative environment. 
THE ONLINE INFOGRAPHIC TASK ALLOWED ME

TO INCREASE MY LANGUAGE SKILLS

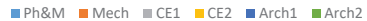

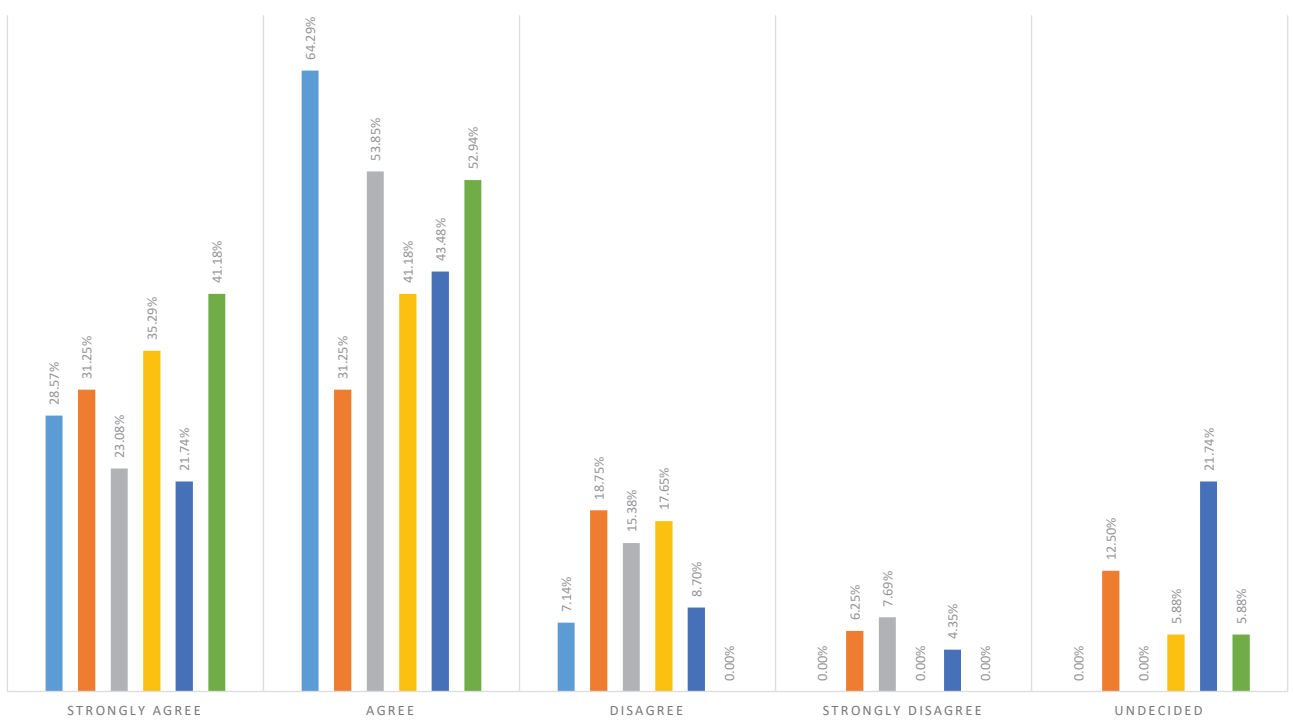

Figure 3. Increase in language skills.

LANGUAGE CLASSES FOR UNIVERSITY STUDENTS SHOULD INCLUDE ONLINE COLLABORATIVE TASKS.

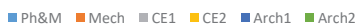

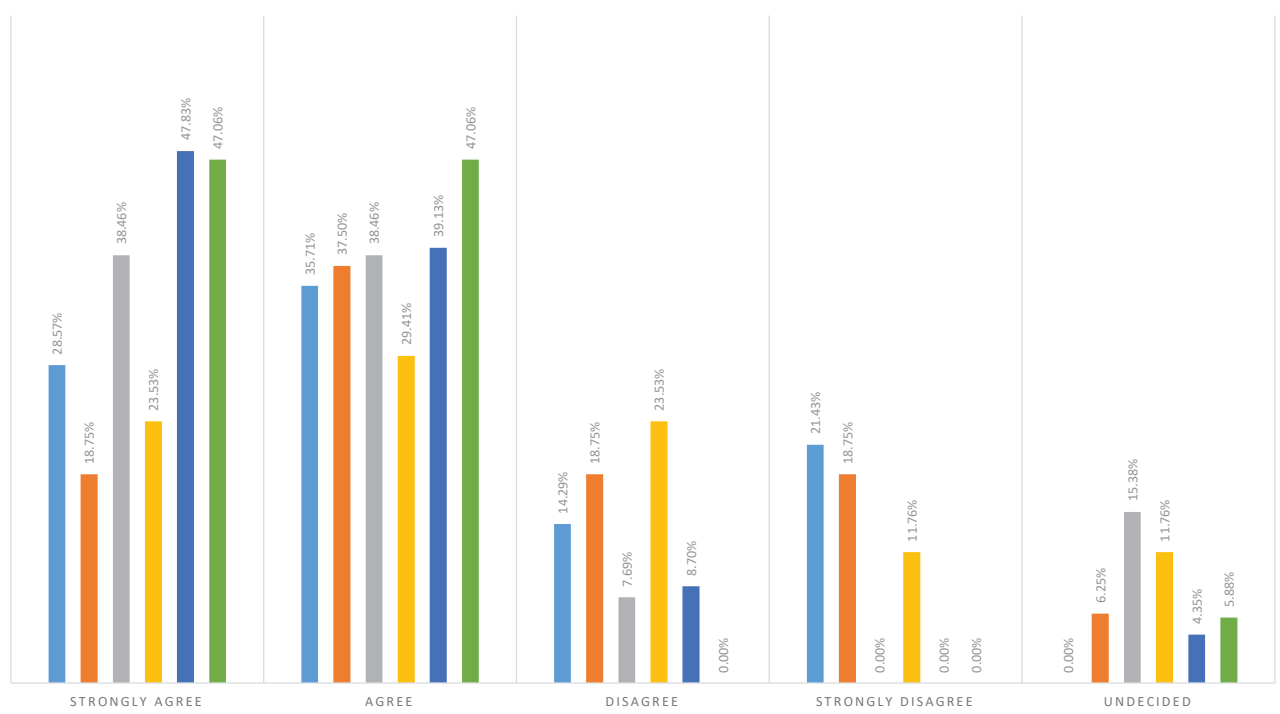

Figure 4. Willingness to participate in online collaborative language classes.

IJREL.2020.6.2.05 p. 12/21 
Online Collaborative Learning to Enhance Educational Outcomes...

Not only the respondents who participated in the data visualisation tasks but also the ones who were involved in developing interactive posters in the previous stage of the research noticed an increase in their soft skills, namely in the collaborative one. Figure 5 shows the data collected in two phases of the research - the latest one in which the students made infographics and the previous one that focused on presenting critically analysed data and specifications. A statistical comparison of the two groups shows that more than half the students appreciated being engaged in online teamwork - the mean in the data visualisation group and in the interactive poster one equals $78.02 \%$ and $63.09 \%$ respectively, with the medians being $76.7 \%$ and $55.56 \%$. There is a statistically significant difference between the responses in both groups $(\mathrm{p}=0.039, \mathrm{p}<0.05)$. However, if there were more respondents in the second group (61 students completed the questionnaire) than in the first one (100 students), an analysis could show no statistically significant difference.

THE ONLINE PROJECT HELPED ME INCREASE COLLABORATIVE SKILLS

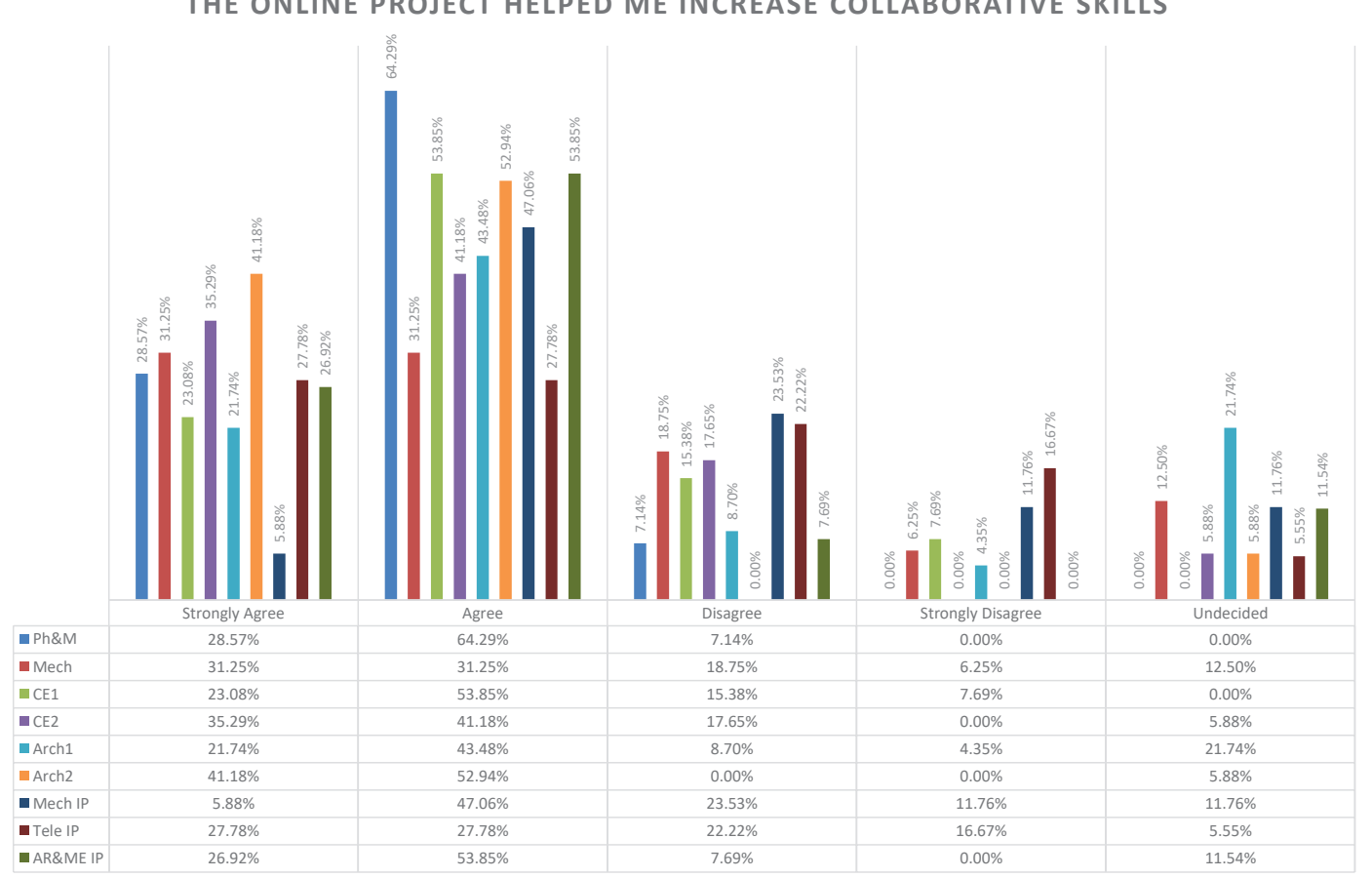

Figure 5. Impact of online projects on collaborative skills.

The respondents used different tools, which might have affected their experiences. All of them were easy to use, free and did not require any technologically advanced knowledge. However, those which were applied to create infographics 
- infogram and venngage - had more functionalities and their affordances were more varied and sophisticated. The respondents had also a wide range of templates to choose from, so they were supported pre-emptively by the tool's authors. The mural, quip, easel.ly tools do not provide users with so many possibilities to create advanced projects as the ones used to build infographics.

As can be seen in Figure 6, no matter which tool was applied and then evaluated, every one contributed to the development of collaborative skills from the point of view of the respondents. A majority of the students regarded the tool they had chosen as suitable for online teamwork (92.86 of Physics and Maths students,

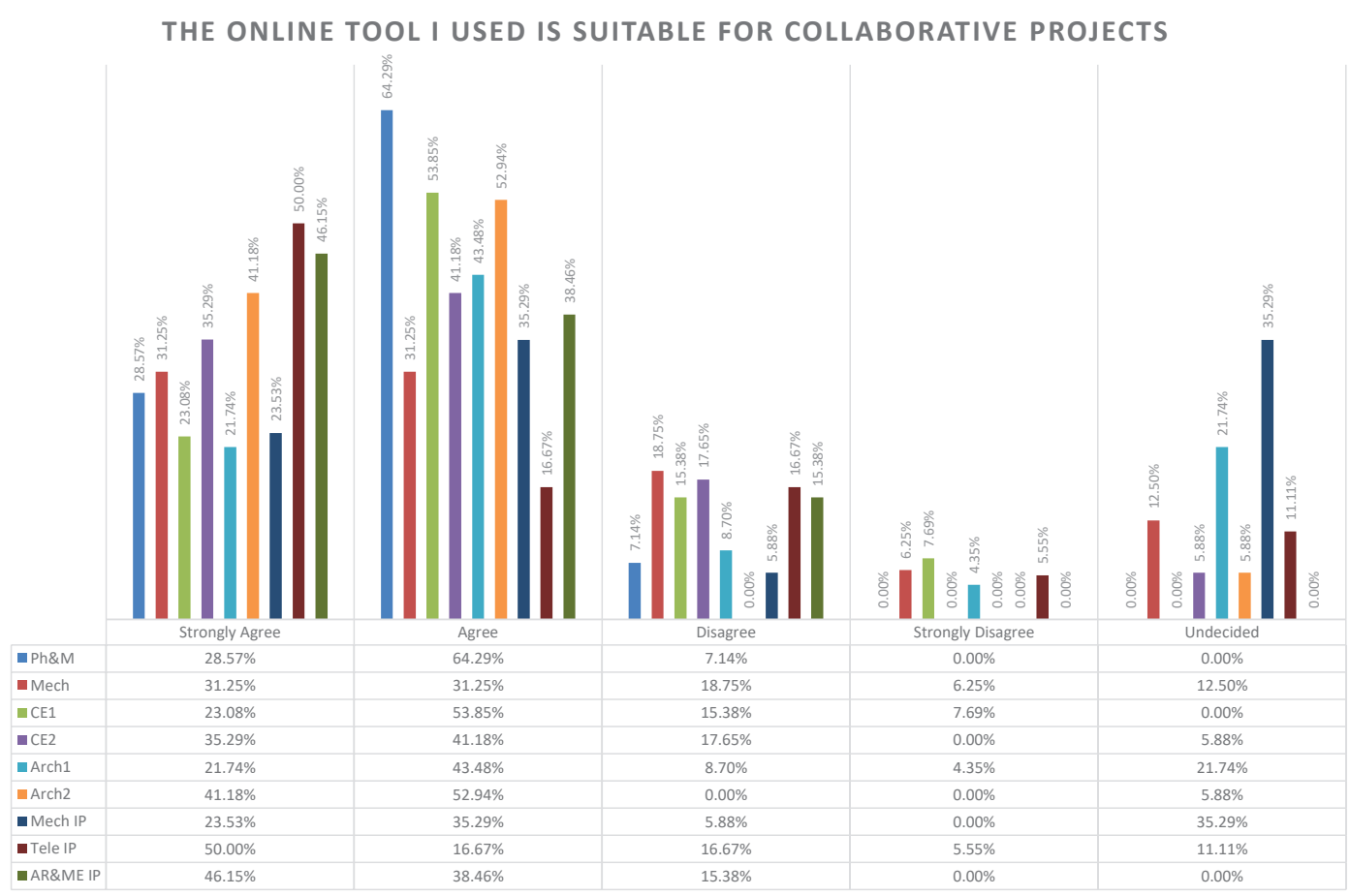

Figure 6. Suitability of online tools for collaborative projects.

$62.5 \%$ of Mechanics students, $76.93 \%$ of Civil Engineering 1 students, $76.47 \%$ of Civil Engineering 2 students, $65.22 \%$ of Architecture 1 students, $94.12 \%$ of Architecture 2 students vs. $58.82 \%$ of Mechanics students, $46.67 \%$ of Telecommunication students, $84.61 \%$ of Automatics, Robotics and Medical Engineering students). The mean values for both groups are $78.02 \%$ (median for 100 participants equals $76.7 \%$ ) and $63.37 \%$ (median for 61 participants equals $58.82 \%$ ). 
Online Collaborative Learning to Enhance Educational Outcomes...

The first research phase showed that there was a significant correlation between the students' evaluation of the wiki tool, which has only basic functionalities, and soft skills development $(\mathrm{p}<0.05)$ - the higher the respondents rated the Moodle tool, the better they evaluated an increase in their collaborative skills (Mokwa-Tarnowska et al., 2018, p. 459) The comparison of the answers given by the two groups, of which each worked with different tools, the first one with more advanced than the second one, shows that all the tools can be used to deliver collaborative projects but there is no correlation between the complexity and sophistication of the tool and an increase in collaborative skills. Like in the previous comparative analysis across groups based on data in Figure 5, the result is considered statistically significant $(\mathrm{p}=0.044, \mathrm{p}<0.05)$. However, the $\mathrm{p}$-value is near the significance threshold of 0.05 , so tests on a larger sample size must be repeated.

\section{Conclusions}

The qualitative research based on the observation of students' behaviour in class during project discussions, in-class presentations of the infographics and posters created during online collaboration, as well as answers to closed-ended questions with "other (specify)" responses and open-ended questions has revealed that the students enjoyed online collaborative work because it was conducted in an elearning environment (dos Reis et al., 2018, p. 12), which was a new experience for most of them. The majority noticed an improvement in their hard competencies.

The productions that the students submitted for formative assessment included well-contextualised vocabulary and adequate grammar structures, as well as showed innovative solutions, particularly seen in the specifications in interactive posters. Thus, the work they had done added to an increase in the knowledge of different issues related to their specialisms. Additionally, they increased language fluency in the range of choice of lexis and grammar used in academic English, appropriateness of discourse, as well as digital literacy, which appear in national curricula and are needed for academic success and future work challenges.

The learning outcomes were particularly satisfactory in terms of the writing skill development, which was seen in follow-up paper-based tests. The average score was higher by $15 \%$ compared to the one in the tests that covered the same range of material, which were introduced in a traditional classroom setting and practiced during coursebook-based activities. The evidence comes from the latest phase of the research in which the students were asked to produce infographics 
and write a description of a graph or a table based on the work. Thus, an online, active and student-centred environment had a more profound impact on an increase in the ability to use specialist vocabulary than traditional classroom teaching, which is more instructionist and much less interactive. This way of engaging students helped them to achieve the learning outcomes structured around communication in an academic environment and in the workplace, as described in the GUT's undergraduate course curriculum for all courses taught across the university.

They also had a chance to practice and increase different soft skills, such as analytical and critical thinking ones, as they were engaged in a critical analysis of data when working with authentic materials (Kołodziejczak et al., 2017). This is in line with the wording of another course outcome, central to TUG's language course curriculum, which states that during a first degree course, students are able to obtain and process information related to their field of study and an academic environment in a foreign language (Mokwa-Tarnowska et al., 2018). A positive attitude expressed by more than two thirds of the respondents results from their understanding of the possibilities of the online learning environment they used. They were involved in analysing data collected in Internet research and critical discussion. This, in turn, also led to their increased media literacy skills, as the majority of the data they studied came from films, documentaries, interactive poster presentations and infographics.

Both the qualitative and quantitative research, based on the observation of the students' behaviour during all project stages and their answers to the survey questions, prove that a web-enhanced academic English course should include online collaborative learning to satisfy various needs, including the authorities' needs related to outcomes.

It is also worth stressing that the students lacked sufficient practice as far as collaboration was concerned, some of them asked to be allowed to work individually at the commencement of their project. The reason they gave was that they did not like working in groups. They found it difficult to get along with others. This reveals that collaborative activities, including online ones, should be included in the syllabus of each university course. The presented research shows that educational programmes supplemented by web-based tasks, online group assignments in particular, may stimulate better engagement in course activities (Woo et al., 2007). They encourage students to explore up-to-date topics related to their study area, and motivate them to develop various hard and soft skills.

The participants of the projects improved their collaborative, analytical and critical thinking competencies and the writing skill in particular. It can also be assumed that the survey itself helped the students develop their reflective skills. After analysing their performance and responding to the questions, their meta- 
Online Collaborative Learning to Enhance Educational Outcomes...

awareness of the learning process increased, which should result in them being able to better self-direct their education in the future. The instructional design of the language courses they attended contributed to meeting the learning outcomes, central to the mission of the university.

\section{Final Remarks}

By participating in online collaborative language tasks, students can learn how to overcome different problems they may face in the future when working both in national and international teams, which is what students are expected to learn in a modern university course, and which is difficult to achieve in a traditional monolingual classroom, where there is a lack of genuine interactions and students feel forced to participate in artificially induced activities. With its affordances, a web-enhanced setting creates more opportunities for the development of adequate knowledge and soft skills. Its complex and versatile nature allows educators to address the students' expectations more explicitly and directly, and helps them achieve learning outcomes structured around key curricular concepts: creativity, communication, teamwork, media literacy and digital competencies.

\section{References}

Anderson, L. W. \& Krathwohl, D. R. (Eds.). (2001). A taxonomy for learning, teaching, and assessing: A revision of Bloom's taxonomy of educational objectives. Longman.

Atkin, J. M., Black, P. \& Coffey, J. (Eds.). (2005). Classroom assessment and the National Science Education Standards / Committee on Classroom Assessment and the National Science Education Standards. National Academy Press.

Astin, A. W. (2012). Assessment for excellence: The philosophy and practice of assessment and evaluation in higher education. Rowman \& Littlefield Publishers.

Beall, G. (2016). 8 Key Differences between Gen Z and Millennials. Retrieved from https://www. huffingtonpost.com/george-beall/8-key-differences-between_b_12814200.html? guccounter=1

Bishop, S. K., Dixon, M. R., Moore, J. W., \& Lundy, M. P. (2016). Behavioral perspectives on personality. In V. Zeigler-Hill \& T. K. Shackelford (Eds.), Encyclopedia of personality and individual differences (1-11). Springer International Publishing AG. https://doi 10.1007/978-3319-28099-8_962-1

Bloom, B., \& Krathwohl, D. (1956). Taxonomy of educational objectives: the classification of educational goals, by a committee of college and university examiners. Handbooks 1 to 3: The cognitive, affective and psychomotor domain. Longmans Green. 
Bloom, B. (Ed.). (1956). Taxonomy of educational objectives, the classification of educational goals - Handbook I: Cognitive domain. McKay.

Clark, D. R. (2004). Bloom's taxonomy of learning domains. Retrieved from http://www.nwlink. com/ donclark/hrd/bloom.html

Cowie, B. \& Bell, B. (1999). A model of formative assessment in science education. Assessment in Education, 6, 101-116.

Crooks, T. (2001). The validity of formative assessments. Paper presented to the British Educational Research Association Annual Conference, University of Leeds, 13-15 September. Retrieved from http://www.leeds.ac.uk/educol/documents/00001862.htm

Dave, R. H. (1975). Psychomotor levels. In R. J. Armstrong (Ed.), Developing and writing behavioural objectives (pp. 33-34). Educational Innovators Press.

Diogo dos Reis, A., Yakovleva, O., Smyrnova-Trybulska, E., \& Morze, N. (2018). From Socratic behaviourism to digital constructivism. International Journal of Research in E-Learning, 4(1), 11-28. https://www.journals.us.edu.plcommunica/index.php/IJREL/article/view/8333

Heriot-Watt University. (1999). Lola: Learning about open learning, training manual. Heriot-Watt University.

Issa, T., Issa, Th., \& Issa, T. B. (2016). Wiki tool in higher education: An Australian perspective. International Journal of Research in E-Learning, 2(1), 11-27. https://www.journals.us.edu.pl/ index.php/IJREL/article/view/8373

Jordan, A., Carlile, O., \& Stack, A. (2008). Approaches to learning: a guide for teachers. Open University Press.

Kemp, N. \& Grieve, R. (2014). Face-to-face or face-to-screen? Undergraduates' opinions and test performance in classroom vs. online learning. Frontiers in Psychology, 5(1278), 1-11. https:// doi:10.3389/fpsyg.2014.01278

Kołodziejczak, B., Mokwa-Tarnowska, I. \& Roszak, M. (2017). Authenticity in developing English for specific purposes. Linguodidactica XXI, 147-163.

Kołodziejczak, B., Roszak, M., Ren-Kurc, A., Kowalewski, W. \& Półjanowicz, W. (2015). Communication tools on e-learning portals. In E. Smyrnova-Trybulska (Ed.), IT tools-good practice of effective use in education (pp. 63-80). Studio Noa.

Krathwohl, D. R., Bloom, B. S. \& Masia, B. B. (1964). Taxonomy of educational objectives, the classification of educational goals - Handbook II: Affective domain. McKay.

Mathur, A. K. (2017). The role of soft skills in enhancing employability of technical graduated: A study. International Journal on Emerging Technologies, 8(1), 65-66.

Mokwa-Tarnowska, I., Roszak, M. \& Kołodziejczak, B. (2018). Online collaborative projects to enhance soft skills. In E. Smyrnova-Trybulska (Ed.) E-learning and Smart Learning Environment for the Preparation of New Generation Specialists. E-learning Series, vol. 10 (pp. 43-464). Studio Noa.

Mokwa-Tarnowska, I. (2017a). E-learning i blended learning w nauczaniu akademickim: zagadnienia metodyczne. Wydawnictwo Politechniki Gdańskiej.

Mokwa-Tarnowska, I. (2017b). Higher interest, deeper concentration, more satisfaction - Web 2.0 tools to enhance technical English classes. In M. Sowa, J. Krajka (Eds.), Innovations in languages for specific purposes, Innovations en langues sur objectifs spécifiques: Present challeng-es and future promises, défies actuels et engagements à venir (pp. 156-167). Peter Lang.

Mokwa-Tarnowska, I. (2017c). Web-enhanced project environment. Writing specifications and creating interactive poster presentations. In M. Hrubý (Ed.), Distance learning, simulation and communication 2017, proceedings (selected papers), Brno, May 31-June 2 (pp. 113-120). University of Defence. 
Online Collaborative Learning to Enhance Educational Outcomes...

NACE (2019), The four career competencies employers value most. https://www.naceweb.org/careerreadiness/competencies/the-four-career-competencies-employers-value-most/

Noskova, T., Pavlova, T., Yakovleva, O., Gutiérrez-Esteban, P., Martin-Espada, R., Cubo-Delgado, S., Arias-Masa, J., Delicado-Puerto, G., Alonso-Dias, L. \& Yuste-Tosina, R. (2017). Some trends of ICT tools application by teachers: A comparative study of Russian and Spanish experience. In E. Smyrnova-Trybulska (Ed.), E-learning vol. 9: Effective development of teachers' skills in the area of ICT and e-learning (pp. 229-238). Studio Noa.

Rima, H. B., Syeda, T. U. \& Lubna, J. R. (2017). The big impact of soft skills in today's workplace. International Journal of Economics, Commerce and Management, 5(1), 456-463.

Scott, D. (Ed.). (2003). Curriculum studies: Vol. IV Boundaries: subjects, assessment, and evaluation. Routledge Falmer. http://books.google.com/books?id=1lc8VhacrD8C\&pg=PA203\&dq=s ummative + assessment $\& \mathrm{~cd}=3 \# \mathrm{v}=$ onepage $\& \mathrm{q}=$ summative $\% 20$ assessment $\& \mathrm{f}=$ false

Skinner, B. F. (1938). The behaviour of organisms. Appleton-Century-Crofts.

Thorndike, E. L. (1911). Animal intelligence. Macmillan.

Widła, H. (2019). Implementation of IT tools as a method of improving language and communication skills of bi- and trilingual students. International Journal of Research in E-Learning, 5(2), 33-48. https://www.journals.us.edu.pl/index.php/IJREL/article/view/8429

Woo, Y., Mehringer, S., Agostinho S. \& Reeves, Th. (2007). Implementing authentic tasks in webbased learning environments. EDUCAUSE Review,3(2007), 36-43 https://er.educause.edu/ / media/files/article-downloads/eqm0735.pdf

Iwona Mokwa-Tarnowska

\title{
Zadania grupowe online wzmacniające efekty uczenia się na zajęciach $\mathrm{z}$ języka angielskiego
}

\author{
Streszczenie
}

Istnieje wiele typów zajęć e-learningowych, blended learningowych i wspomaganych komponentami online. W zależności od nauczanych przedmiotów, kierunku i stopnia studiów, mają one zaspakajać zróżnicowane cele główne i szczegółowe zapisane w sylabusach. Bez względu na założenia konstrukcyjne, w każdym kursie internetowym lub wspomaganym narzędziami online widać inspiracje ideami behawiorystycznym. Mają one duży wpływ na sposób formułowania celów i język instrukcji, a w szczególności na konceptualizację efektów uczenia się. Widoczne jest to również w zapisach dotyczących tradycyjnych zajęć prowadzonych w sali wykładowej, seminaryjnej i laboratorium. Wykorzystanie licznych narzędzi online, oferujących różnorodne funkcjonalności, przyczynia się do znacznego zwiększenia możliwości interakcyjnych, niedostępnych w tradycyjnym, instrukcjonistycznym środowisku uczenia się i nauczania. Zajęcia z języka angielskiego przeznaczone dla studentów szkół wyższych, wykorzystujące komponenty e-learningowe, mogą stymulować do nauki poprzez aktywności skutkujące rozwojem wielu umiejętności potrzebnych w przyszłej pracy - kompetencji zarówno twardych, jak i miękkich. Dzięki wykorzystaniu narzędzi online do prowadzenia projektów grupowych można stworzyć bardziej autentyczne środowisko edukacyjne, przypominające sytuacje mające miejsce w życiu codziennym i zawodowym. Ułatwi ono studentom osiągnięcie zapisanych w sylabusach kursów językowych efektów uczenia 
się, ukierunkowanych na nabycie przez nich umiejętności komunikacji, pracy zespołowej, korzystania z mediów oraz na rozwinięcie kompetencji językowych. W niniejszym artykule zaprezentowano wyniki badań nad efektywnością nauczania online, w których poddano analizie opinie studentów Politechniki Gdańskiej wyrażone w ankietach przeprowadzonych w latach 2017-2019.

S łow a k lu c z o we: uczenie się języka angielskiego w szkole wyższej, narzędzia online, umiejętności twarde i miękkie, e-learning, projekty zespołowe

Ивона Моква-Тарновска

\section{Совместное онлайн-обучение для улучшения результатов обучения на курсах английского языка}

Анно т а ция

Различные цели и задачи программы электронного обучения, смешанного обучения и веб-курсов, которые предназначены для определенных групп студентов или аспирантов, могут существенно различаться. Какими бы разными они ни были, они могут демонстрировать бихевиористские идеи, воплощенные в учебном дизайне. Множество онлайн-инструментов (текстовых, графических, мультимодальных и совместных) могут улучшить учебный опыт учащихся, поскольку блфгодаря им предлагаются возможности для взаимодействия, недоступные в традиционной, инструктивистской концепции классе. Таким образом, университетский языковой курс с веб-компонентами предлагает более универсальные возможности обучения, чем очные занятия, что может привести к тому, что студенты станут более компетентными и конкурентоспособными сотрудниками в ближайшие годы. Используя онлайн-инструменты, такие как ThingLink, фрески, шутки, easel.ly, инфограммы для сбора и критического анализа данных, они учатся по-новому, в более реальной среде. Такой способ заангажирования студентов помогает им достичь результатов обучения, основанных на общении, командной работе, медиаграмотности и языковых навыках. Эти идеи подтверждаются мнениями и отношением студентов, выраженными в опросах, проведенных в Гданьском технологическом университете в 2017-2019 годах.

К л ю ч е в ы е с ло в а: изучение языков через Интернет, онлайн-инструменты, твердые и мягкие навыки, электронное обучение, университетское образование, совместный проект

IJREL.2020.6.2.05 p. 20/21 
Online Collaborative Learning to Enhance Educational Outcomes...

Iwona Mokwa-Tarnowska

\title{
Aprendizaje colaborativo en línea para mejorar los resultados educativos de los cursos de idioma inglés
}

\author{
Resumen
}

Con varios propósitos y objetivos, los programas de aprendizaje en línea, el aprendizaje combinado y los cursos mejorados por la web destinados a un grupo particular de estudiantes universitarios o posgraduados pueden variar sustancialmente. Por diferentes que sean, es probable que muestren ideas conductistas incorporadas en el diseño instruccional. Una plétora de herramientas en línea (basadas en texto, basadas en imágenes, producción multimodal y colaborativas) pueden aumentar las experiencias de aprendizaje de los estudiantes, ya que ofrecen oportunidades para interacciones que no están disponibles en un aula instructivista tradicional. Por lo tanto, un curso universitario de idiomas con componentes mejorados en la web ofrece opciones de aprendizaje más versátiles que las clases presenciales, lo que puede hacer que los estudiantes se conviertan en trabajadores más competentes y competitivos en los próximos años. Al utilizar herramientas en línea como ThingLink, mural, quip, easel.ly, infogram para recopilar y analizar datos de manera crítica, aprenden de una manera nueva y activa, en un entorno más genuino. Esta forma de involucrar a los estudiantes les ayuda a lograr resultados de aprendizaje estructurados en torno a la comunicación, el trabajo en equipo, la alfabetización mediática y las habilidades lingüísticas. Estas ideas están respaldadas por las opiniones y actitudes de los estudiantes expresadas en las encuestas realizadas en la Universidad Tecnológica de Gdańsk en los años 2017-2019.

Palabras clave: aprendizaje de idiomas mejorado por la web, herramientas en línea, habilidades duras y blandas, e-learning, educación universitaria, proyecto colaborativo 
